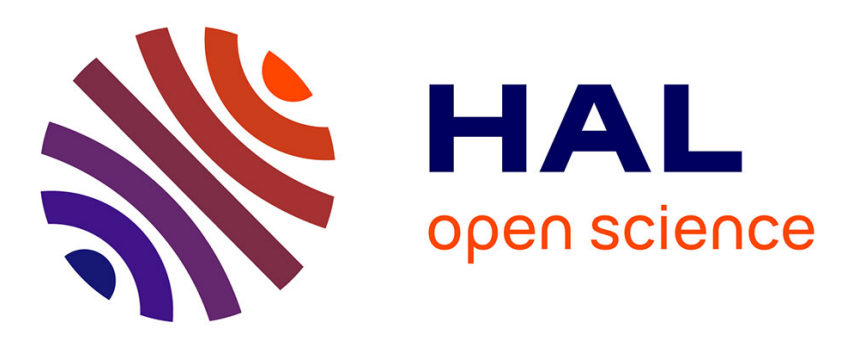

\title{
Variability of the hemocyte parameters of Ruditapes philippinarum in the field during an annual cycle
} Jonathan Flye-Sainte-Marie, Philippe Soudant, Christophe Lambert, Nelly Le

Goïc, Madeleine Goncalvez, Marie-Agnès Travers, Christine Paillard, Fred Jean

\section{To cite this version:}

Jonathan Flye-Sainte-Marie, Philippe Soudant, Christophe Lambert, Nelly Le Goïc, Madeleine Goncalvez, et al.. Variability of the hemocyte parameters of Ruditapes philippinarum in the field during an annual cycle. Journal of Experimental Marine Biology and Ecology, 2009, 377 (1), pp.1-11. 10.1016/j.jembe.2009.06.003 . hal-00452255

\section{HAL Id: hal-00452255 \\ https://hal.univ-brest.fr/hal-00452255}

Submitted on 11 Feb 2010

HAL is a multi-disciplinary open access archive for the deposit and dissemination of scientific research documents, whether they are published or not. The documents may come from teaching and research institutions in France or abroad, or from public or private research centers.
L'archive ouverte pluridisciplinaire HAL, est destinée au dépôt et à la diffusion de documents scientifiques de niveau recherche, publiés ou non, émanant des établissements d'enseignement et de recherche français ou étrangers, des laboratoires publics ou privés. 


\title{
Variability of the hemocyte parameters of Ruditapes philippinarum in the field during an annual cycle.
}

\author{
Jonathan Flye-Sainte-Marie ${ }^{\mathrm{a}, \mathrm{b}}$, Philippe Soudant ${ }^{\mathrm{a}, \mathrm{b}}$, \\ Christophe Lambert ${ }^{\mathrm{a}, \mathrm{b}}$, Nelly Le Goïc ${ }^{\mathrm{a}, \mathrm{b}}$, Madeleine Goncalvez ${ }^{\mathrm{a}, \mathrm{b}}$, \\ Marie-Agnès Travers ${ }^{\mathrm{a}, \mathrm{b}}$, Christine Paillard ${ }^{\mathrm{a}, \mathrm{b}}$, Fred Jean ${ }^{\mathrm{a}, \mathrm{b}, *}$. \\ ${ }^{a}$ Université Européenne de Bretagne, France \\ ${ }^{\mathrm{b}}$ Université de Brest ; CNRS (CNRS/INSU) UMR 6539 LEMAR, IUEM, Place N. \\ Copernic, 29280 Plouzané, France
}

\begin{abstract}
A field monitoring of hemocyte parameters of the Manila clam Ruditapes philippinarum was conducted from July 2004 to September 2005 in Gulf of Morbihan (France), in order to assess (1) the factors controlling the hemocyte parameters of the Manila clam and (2) their relative contribution to the overall variability of these parameters. Monthly, sixty clams were sampled and Total Hemocyte Count (THC), granulocyte and hyalinocyte counts, phagocytosis, phenoloxidase specific activity, length, flesh dry weight, and condition index were measured individually. Perkinsus sp. infection and Brown Ring Disease symptoms were also monitored.Temperature and trophic resource were also monitored.
\end{abstract}

Results indicate that temperature controls granulocyte counts and subsequently THC. Other environmental factors had no direct influence on the measured hemocyte parameters. Almost all measured parameters were significantly affected by size/age and condition index. There were poor relationships between both pathologies and hemocyte parameters presumably because of low infection intensities. Nevertheless, high Perkinsus sp. infection intensity significantly increased total and granulocyte counts and decreased phagocytosis.

An interesting result of this study is that the measured biotic and abiotic factors poorly contribute to the explanation of the total variability of hemocyte parameters. Granulocyte concentration was the best explained parameter. However, only $16.4 \%$ of its variance was explained by cumulating temperature, length, condition index and Perkinsus sp. infection effects. This study emphasizes the need for a better understanding of hemocyte functions and the factors modulating these functions.

Key words: Hemocyte parameters, Environmental factors, Variability, Manila clam, Brown Ring Disease, Perkinsus

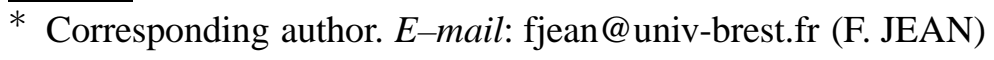




\section{Introduction}

The Manila clam Ruditapes (=Tapes, =Venerupis) philippinarum is one of the most extensively cultivated bivalve molluscs. This species was originally endemic to Indo-Pacific waters and its high adaptive capacity to various rearing environments made of it a target species for aquaculture. In Europe, this species was first introduced in France between 1972 and 1975 for aquaculture purposes and later in England, Spain and Italy (Flassch and Leborgne, 1992). In the late 1980s, natural population have developed in Italy (Marin et al., 2003), in England (Jensen et al., 2004; Humphreys et al., 2007) and in most embayments along the French Atlantic coast, resulting in a fishery of ca. 1500 tons in the Gulf of Morbihan at the end of the 1990s. This species is mainly affected by two pathologies: Brown Ring Disease (BRD) and Perkinsosis (see e.g. Paillard, 2004b; Villalba et al., 2004). Brown ring disease is caused by the bacterium Vibrio tapetis (Paillard and Maes, 1990; Borrego et al., 1996) which disrupts the production of periostracal lamina and causes an anomalous deposition of periostracum on the inner shell (Paillard and Maes, 1995a,b). Perkinsosis is induced by the protozoan parasite Perkinsus sp. and can affect both Ruditapes decussatus and R. philippinarum (see Villalba et al., 2004, for a review). Both pathologies can interfere with host energy balance (Ngo and Choi, 2004; Park et al., 2006; Leite et al., 2004; Flye-Sainte-Marie et al., 2007b) and can be responsible for mass mortalities (see e.g. Paillard et al., 1989; Castro et al., 1992; Paillard, 1992, 2004b; Villalba et al., 2005, 2004). Epidemiological surveys also showed that both pathologies have also been shown to be influenced by environment factors (Paillard et al., 1997; Villalba et al., 2005). Different laboratory experiments have been performed to assess the effect of environmental factors (temperature and salinity) on celluar-defence related parameters (Reid et al., 2003; Paillard et al., 2004) in link with pathologies and few field studies assessed the seasonal variation of these parameters (Matozzo et al., 2003; Soudant et al., 2004). Collection of field data is needed to better understand the relationships between environmental factors, defence-related parameters, physiological status and disease development.

Mainly as a result of aquaculture and fisheries industry and associated disease events, hemocyte system, thought to be involved in immune response of bivalves, were extensively studied during the past 30 years. More recently appeared the interest in using bivalve hemocyte parameters as biomarkers of environmental perturbations. Numbers of studies allowed to show that hemocyte parameters are controlled by numerous factors such as environmental factors (temperature and salinity), parasites and internal factors (reproduction; see review in Chu, 2000). These factors may contribute to explain the high degree of variability of the hemocyte responses and activities which has been reported only in few studies (see e.g. Ashton-Alcox and Ford, 1998; Ford and Paillard, 2007). In the aim of better understanding the linkages between environment, host physiology and disease development, the relative contribution of biotic and abiotic factors to the overall variability of the hemo- 
cyte parameters in the field is a key question and remains poorly known.

A multiparametric study was designed to assess the relative effect of environmental and internal factors and diseases on hemocyte parameters in the field. Gulf of Morbihan is one of the largest Manila clam fisheries of Brittany. Meanwhile, information on the physiology and reproduction of the Manila clam of Gulf of Morbihan are available (Laruelle et al., 1994; Laruelle, 1999; Calvez, 2003). Manila clams populations from this site are known to be moderately affected by both BRD and perkinsosis (Paillard et al., 1997; Paillard, 2004a,b; Lassalle et al., 2007). Seasonal variations were taken into account by monthly sampling over a 1-year period. Flow cytometry methods were applied to determine hemocyte counts, viability and phagocytosis activity.

\section{Materials and methods}

\subsection{Clam sampling}

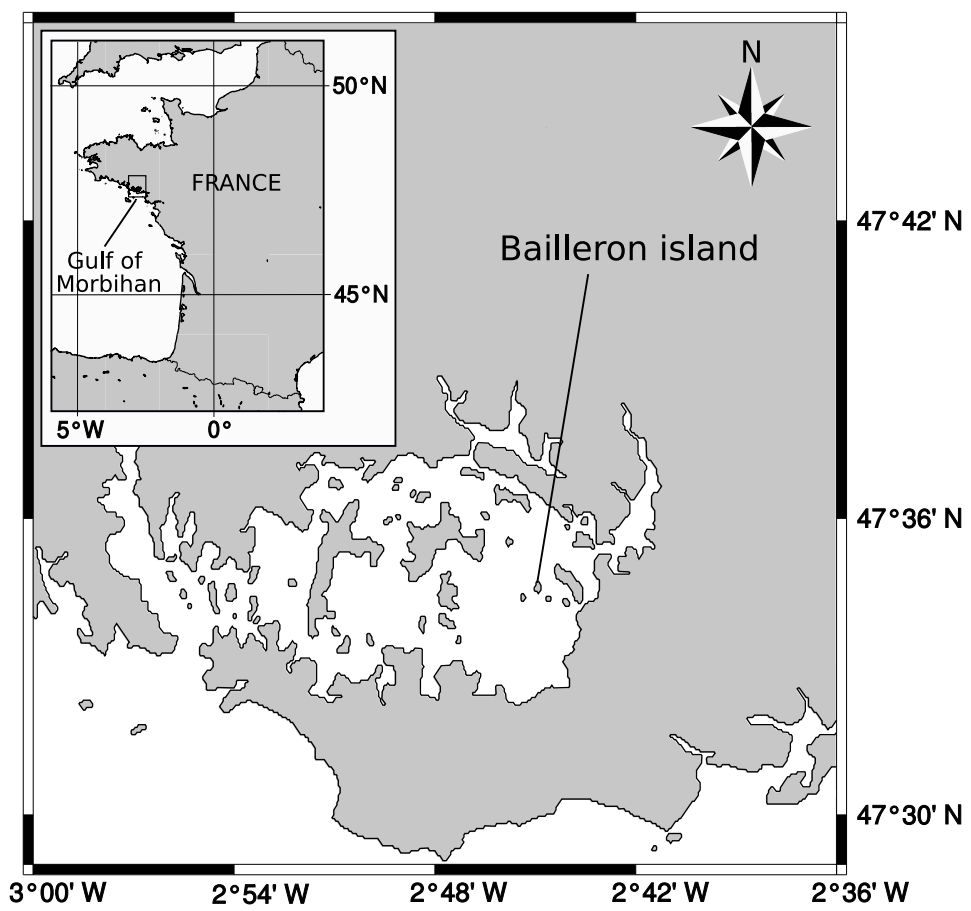

Fig. 1. Location of Bailleron island in Gulf of Morbihan, Southern Brittany, France.

From July 2004 to September 2005, 60 R. philippinarum ranging from $20 \mathrm{~mm}$ to $50 \mathrm{~mm}$ were monthly sampled at low tide from the natural clam bed of Bailleron island in Gulf of Morbihan, southern Brittany, France (Fig. 1). Clams were stored 
in an icebox until being processed in the laboratory. A total of 1020 individuals was sampled from 17 sampling dates. At each sampling date, 60 clams were processed individually according to the protocol that follows.

\subsection{Analysis of hemocyte parameters by flow cytometry}

\section{Hemolymph sampling}

A minimum of $450 \mu \mathrm{L}$ of hemolymph was withdrawn from the adductor muscle of individual clams using a $1 \mathrm{~mL}$ plastic syringe fitted with a 25 -gauge needle and observed under microscope to control the sample and sampling qualities. Hemolymph samples were filtered through a $80 \mu \mathrm{m}$ mesh in order to eliminate large debris and were stored individually in $1.5 \mathrm{~mL}$ micro-tubes held on ice.

\section{Instrumentation}

Analysis of hemocyte parameters were performed using a FACScalibur flow cytometer (Becton-Dickinson, San Diego, CA, USA) equipped with a $488 \mathrm{~nm}$ argon laser. The light scattered by particles indicated (1) their size through the FSC detector (Forward SCatter height) and (2) their internal complexity through the SSC detector (Side SCatter height). The flow cytometer is equipped with three specific fluorescence sensors: FL1 (green, 500-530 nm), FL2 (orange, 550-600 nm) and FL3 (red, $>630 \mathrm{~nm}$ ) allowing the detection of autofluorescence or fluorescent dyes.

\section{Hemocyte viability, total and differential hemocyte counts (THC and DHC)}

These parameters were measured following the protocol developed by Delaporte et al. (2003). Briefly, $100 \mu \mathrm{L}$ of hemolymph from each individual were added in a tube containing $200 \mu \mathrm{L}$ of anti-aggregant solution for bivalve hemocytes (AASH; Auffret and Oubella, 1994) and $100 \mu \mathrm{L}$ of filtered sterile seawater (FSSW). Samples were incubated $2 \mathrm{~h}$ at $18^{\circ} \mathrm{C}$ in dark conditions with $4 \mu \mathrm{L}$ of SYBR Green working solution (obtained by diluting $10 \mathrm{x}$ the commercial solution; Molecular probes, Oregon, USA) and propidium iodide (PI, Sigma) at a final concentration of $10 \mu \mathrm{g} \mathrm{mL}^{-1}$. Live and dead cells containing DNA are stained by SYBR Green; whereas, dead cells are only stained by PI. SYBR Green fluorescence is detected by the FL1 detector of the flow cytometer, and PI fluorescence is detected by the FL3 detector. By using a density plot visualisation of FL1 vs FL3, it was possible to estimate precisely the percentage of dead cells in each sample.

A density plot visualisation of SSC vs FL1 allowed differentiation and gating of hemocytes stained by SYBR green from other particles in the hemolymph. This 
allowed to calculate THC by taking into account the flow rate of the cytometer calculated according to the method of Marie et al. (1999).

Similarly to Allam et al. (2002a), two distinct sub-populations could be identified on a FSC vs SSC density plot: granulocytes (high SSC and high FSC), hyalinocytes (low SSC and high FSC). Results of THC, granulocyte and hyalinocyte counts are expressed as number of cells per $\mathrm{mL}$ of hemolymph.

\section{Phagocytosis assays}

Phagocytic activity of hemocytes was measured following the protocol described in Delaporte et al. (2003) and Labreuche et al. (2006) using $2 \mu \mathrm{m}$ diameter latex fluorescent beads (fluoresbrite microspheres YG 2.0 microns, polysciences, Eppelheim, Germany). A $150 \mu \mathrm{L}$ sub-sample of hemolymph, primarily diluted with 150 $\mu \mathrm{L}$ of FSSW, was brought in contact with $30 \mu \mathrm{L}$ of the working solution of fluorescent beads (obtained by diluting $50 \mathrm{x}$ the commercial solution) in micro-tubes. Tubes were incubated for $2 \mathrm{~h}$ at $18^{\circ} \mathrm{C}$ in dark condition. Analysis by flow cytometry allowed to detect hemocytes containing fluorescent beads on the FL1 detector. The phagocytic activity of hemocytes was calculated as the percentage of hemocytes that have ingested three fluorescent beads or more.

\section{Phenoloxidase activity}

Ninety-six-well plates containing $100 \mu \mathrm{L}$ hemolymph samples were thawed and phenoloxidase activity measured as described by Reid et al. (2003). Briefly, 50 $\mu \mathrm{L}$ of Tris- $\mathrm{HCl}$ buffer $(0.2 \mathrm{M}, \mathrm{pH}=8)$ with $100 \mu \mathrm{L}$ of $\mathrm{L}-\mathrm{DOPA}(20 \mathrm{mM}, \mathrm{L}-3,4-$ dihydrophenyl-alanine, Sigma D9628) were added to each well. The microplate was rapidly mixed for $10 \mathrm{~s}$. The reaction was then measured at ambient temperature with colour change recorded every $5 \mathrm{~min}$, at $492 \mathrm{~nm}$, over a period of $1 \mathrm{~h}$. The microplate was mixed again prior to each measurement. Controls, without hemolymph, but containing L-DOPA and Tris-SDS buffer, were run in parallel and the values subtracted from test values to correct for possible auto-oxidation of the L-DOPA. Hemolymph protein concentration of each individual was determined from thawed 50- $\mu \mathrm{L}$ hemolymph samples using a BCA Protein Assay Kit (Pierce, USA) with bovine serum albumin as a standard, following the manufacturer's guide for the Microwell plate protocol. Results of the specific PO activity were expressed in arbitrary units : 1 A.U. $=\Delta \mathrm{DO}_{490 \mathrm{~nm}} \mathrm{~min}^{-1} \mathrm{mg}_{\text {protein }}{ }^{-1}$. 


\subsection{Diseases}

\section{Detection and quantification of Perkinsus sp. infection}

Detection and quantification of Perkinsus sp. were performed in gills since Choi et al. (2002) showed that the total number of Perkinsus sp. cells in the whole clams is linearly correlated with the number of Perkinsus cells in the gill tissue. After hemolymph sampling, clams were opened using a scalpel, gills were dissected and wet weighted. Perkinsus sp. presence and infection intensity in the gills were assessed according to the quantitative method of Ray (1966) as modified by Choi et al. (1989). Gills of individual clams incubated in $10 \mathrm{~mL}$ of fluid thioglycollate medium (FTM, Difco) supplemented with $67 \mu \mathrm{g}$ of streptomycin (Sigma) and $32 \mu \mathrm{g}$ of penicilin $\mathrm{G}$ (Sigma) dissolved in $100 \mu \mathrm{L}$ in distilled water to limit bacterial growth. Vials were then incubated at room temperature over one week in the dark. Perkinsus cells were then counted after dissolving the FTM cultivated clam gills with $2 \mathrm{M}$ $\mathrm{NaOH}$ according to Choi et al. (1989).

Characterisation and classification of Brown Ring Disease (BRD) syndrome

BRD symptoms were monitored on the inner surface of the clams shells according to the description of Paillard and Maes (1994): conchiolin deposit stage (CDS) range from microscopic brown spots on the inner face of the shell in the earliest stage (CDS 1), to a thick brown deposit covering most of the inner shell in the most advanced stage (CDS 7).

\subsection{Biometric measurements}

After gill dissection, remaining flesh were removed from the shell and placed in pre-weighted aluminium capsules. Capsules were then freeze-dried for $48 \mathrm{~h}$ and dry flesh were weighted. As gills were removed for Perkinsus sp. diagnosis, total flesh dry weight were calculated by adding dry flesh weight and gills dry weight. Gills dry weight were estimated from wet gills weight using the coefficient 0.153 $\mathrm{g}$ dry $\mathrm{g}$ wet estimated from clams collected in Bailleron island (additional samples, $\mathrm{n}=25$; S.D. $=0.008)$.

Shells were air dried and weighted. Length following the maximum length axis was then measured using an electronic caliper and shells were stored until BRD diagnosis. 
Condition index was calculated using the following formula:

$$
C I=\frac{\text { Flesh Dry Weight }}{\text { Shell Dry Weight }} \times 100
$$

\subsection{Environmental factors}

Temperature and salinity In situ sediment temperature was measured using an autonomous temperature data logger (EBI-85A, Ebro, Germany) embedded at $5 \mathrm{~cm}$ in the sediment, the depth at which Manila clam are usually found. The probe measured temperature every $20 \mathrm{~min}$. A daily average was then calculated. Salinity data were provided by IFREMER laboratory of La Trinité-sur-Mer (LER-MPL) and were measured using a Micrel probe in Fort Espagnol were salinity variation are supposed to be correlated to that in Bailleron island.

Trophic resource The monitoring of trophic resource begun in September 2004. Water samples were collected weekly at $50 \mathrm{~cm}$ above the sediment, and stored in a freezer $\left(-18^{\circ} \mathrm{C}\right)$ until further analysis. For each water sample, six sub-samples were filtered through pre-weighted GF/F filters $(25 \mathrm{~mm})$ and freeze-dried to constant weight, and allowed to measure total suspended particulate matter (TPM). Three of the six filters were burnt $\left(4 \mathrm{~h}, 450^{\circ} \mathrm{C}\right)$ and allowed to measure suspended particulate inorganic matter (PIM). Particulate organic matter (POM, $\mathrm{mg} \mathrm{L}^{-1}$ ) was calculated by subtracting TPM and PIM. Burnt and unburnt filters were analysed for total carbon and nitrogen on a CE Instruments NC2500 elemental analyser (CE Elantech, USA). Particulate organic carbon (POC, $\mathrm{mg} \mathrm{L}^{-1}$ ) and nitrogen (PON, $\mathrm{mg} \mathrm{L}^{-1}$ ) were then calculated by subtracting particulate carbon from unburnt and burnt filters. The choice of characterisation of suspended organic matter quantity $(\mathrm{POM})$ and quality (COP and $\mathrm{NOP}$ ) rather than chlorophyll a to estimate trophic resource for the Manila clam was motivated by a modelling study that emphasized that chlorophyll a was not a good estimator of trophic resource for the Manila clam (Flye-Sainte-Marie et al., 2007a).

\subsection{Statistical analysis}

Statistical analysis were performed using the $\mathrm{R}$ software ( $\mathrm{R}$ Development Core Team, 2006). Differences in hemocyte parameters among sampling dates were tested using Kruskal-Wallis test, differences in prevalence of both disease among sampling dates were tested using a $\chi^{2}$ test. Relationships between environmental factors and hemocyte parameters were assessed by the mean of linear models. 
When seasonal effect on a biological variable was significant (i.e. hemocyte parameters and condition index), it was removed to test the relationships between those variables and between hemocyte parameters and length or sex. Seasonal trend was considered to be represented by the variations of the mean of the considered biological variable in healthy individuals (i.e. BRD-asymptomatic and null Perkinsus sp. clams), as along sampling dates. The season detrended value of the variable was calculated for each individual as:

$$
D_{s}=X_{t n}-\bar{X}_{t H}
$$

Where $D_{s}$ is the season detrended residual, $X_{t n}$ is the original value of the variable on sampling date $t$ for individual $n$ and $\bar{X}_{t H}$ is the mean of the variable on sampling date $t$ calculated for healthy clams.

Length of clams had a significant effect on THC, concentration of both granulocytes and hyalinocytes, and on proportion of dead cells in healthy clams. Size of clams also had a significant effect on prevalence for both pathologies. In order to test for the effect of pathologies independently of size, a linear model was used to calculate the effect of length on each of those variables among healthy clams; residuals of these models were used in further calculations for testing the potential effect of pathologies on those hemocyte parameters.

To assess effect of categorical factors (i.e. infected versus non infected), $t$-test was used for normal-distributed data. Fisher test for homogeneity of variance was performed, if variances were significantly different Welsch approximation to the degrees of freedom was used. Wilcoxon test was used for non-normal data. Effect of continuous factors (i.e. length) on hemocyte parameters were assessed using linear models.

\section{Results}

\subsection{Environmental factors}

Average daily temperature in the sediment varied between 6 and $23^{\circ} \mathrm{C}$ (Fig. 2 A) during the sampling period. Temperature and salinity profiles were highly correlated (Fig. $2 \mathrm{~A}$; Pearson $r=0.66, p$-value $=610^{-3}$ ). Particulate organic matter (POM, Fig. 2 B) was highly correlated to particulate organic carbon (POC) and particulate organic nitrogen (PON) (Pearson $r>0.94, p$-value $<10^{-3}$ ). 

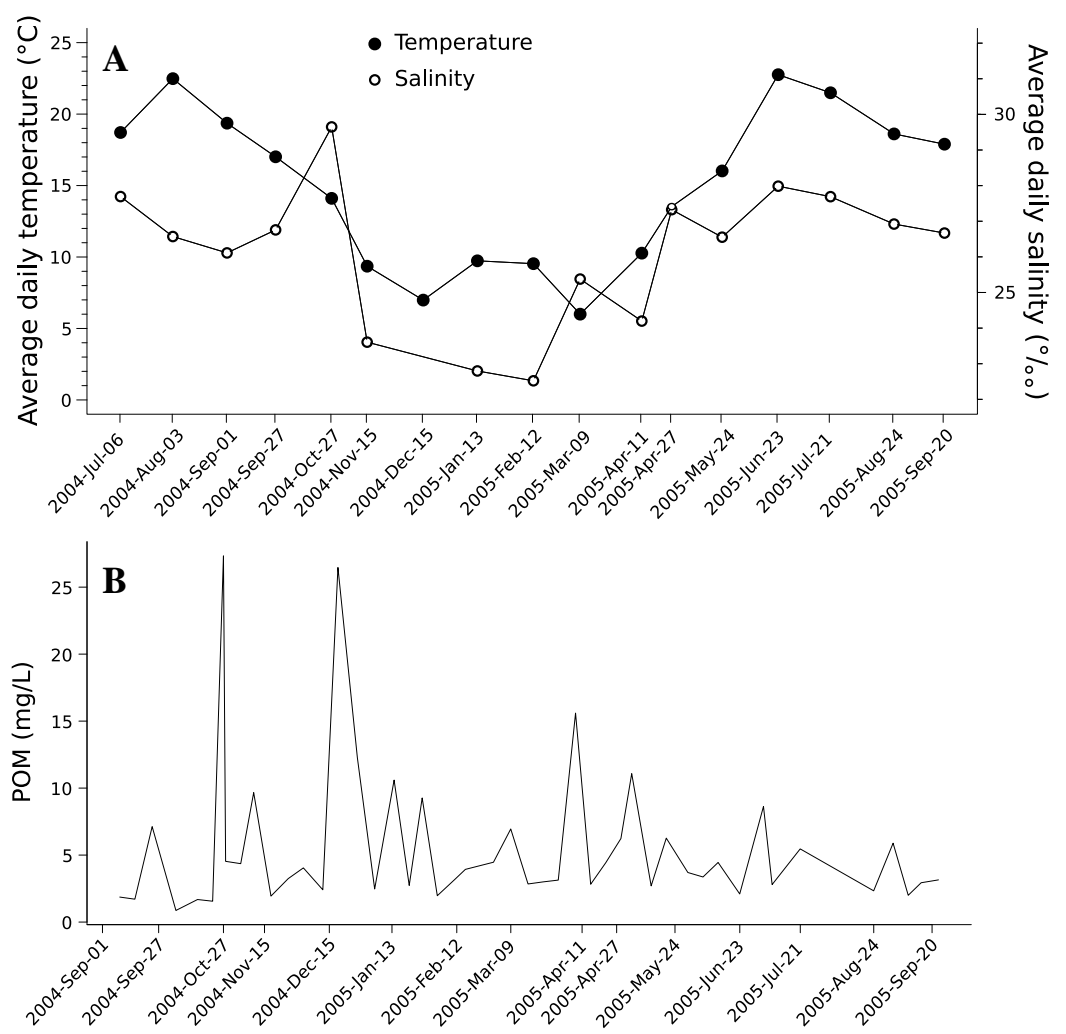

Fig. 2. Evolution of environmental factors during the studied period. A: daily average temperature in the sediment and salinity at the sampling dates. B: evolution of particulate organic matter (POM).

\subsection{Influence of environmental factors on hemocyte parameters}

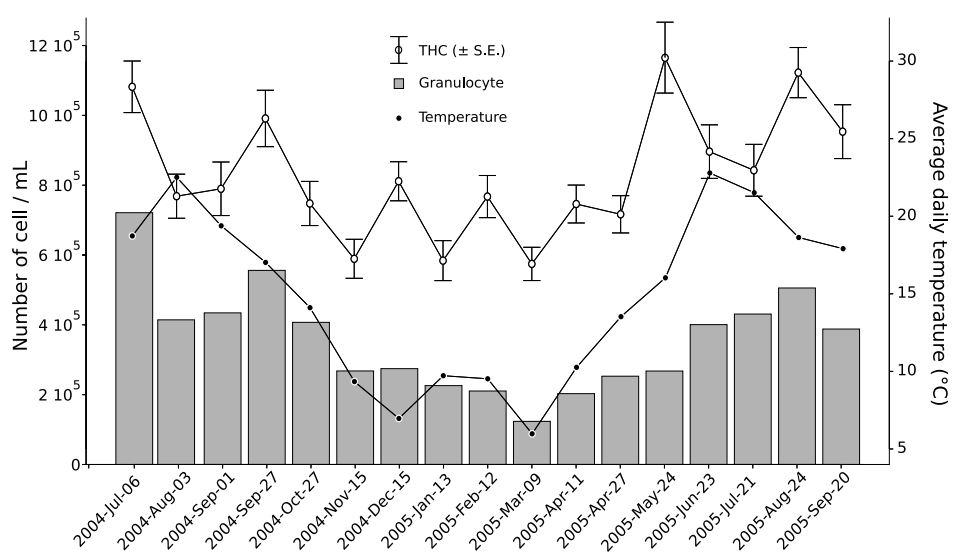

Fig. 3. Evolution of Total Hemocyte Count (THC, bars indicate standard error ), granulocyte concentrations and temperature during the studied period.

Evolution of hemocyte counts (total hemocyte and granulocyte counts) are shown in Fig. 3. All hemocyte parameters significantly varied during the sampling period (Kruskal-Wallis test; $p$-values $<0.005$ ). Nevertheless, there were few significant relationships between hemocyte parameters and measured environmental fac- 
Table 1. Relationships between environmental factors and hemocyte parameters tested using linear models. POM: particulate organic matter, POC particulate organic carbon, PON, particulate organic nitrogen.

\begin{tabular}{|c|c|c|c|c|c|c|c|c|c|c|}
\hline \multirow[t]{3}{*}{ Hemocyte parameter } & \multirow{2}{*}{\multicolumn{2}{|c|}{$\begin{array}{c}\text { Temperature } \\
\left({ }^{\circ} \mathrm{C}\right)\end{array}$}} & \multirow{2}{*}{\multicolumn{2}{|c|}{$\begin{array}{c}\text { Salinity } \\
(\% \circ)\end{array}$}} & \multicolumn{6}{|c|}{ Trophic resource } \\
\hline & & & & & \multicolumn{2}{|c|}{$\mathrm{POM}\left(\mathrm{mg} \mathrm{L}^{-1}\right)$} & \multicolumn{2}{|c|}{ POC $\left(\mathrm{mg} \mathrm{L}^{-1}\right)$} & \multicolumn{2}{|c|}{$\mathrm{PON}\left(\mathrm{mg} \mathrm{L}^{-1}\right)$} \\
\hline & slope & $p$-value & slope & $p$-value & slope & $p$-value & slope & $p$-value & slope & $p$-value \\
\hline THC $\left(\right.$ cell mL $\left.{ }^{-1}\right)$ & $1.710^{4}$ & $*$ & $4.510^{4}$ & NS & $-4.210^{4}$ & NS & $-3.910^{4}$ & NS & $-2.910^{5}$ & NS \\
\hline Granulocytes (cell mL $\mathrm{mL}^{-1}$ ) & $1.710^{4}$ & $* *$ & $4.610^{4}$ & * & $-1.710^{4}$ & NS & $3.010^{3}$ & NS & $6.110^{4}$ & NS \\
\hline Hyalinocytes (cell mL ${ }^{-1}$ ) & $-1.210^{3}$ & NS & $-3.910^{3}$ & NS & $-2.210^{4}$ & NS & $-3.810^{4}$ & NS & $-3.210^{5}$ & NS \\
\hline Aggregates $\left(\mathrm{nb} \mathrm{mL}^{-1}\right)$ & $1.310^{3}$ & $*$ & $2.410^{3}$ & NS & $-2.910^{3}$ & NS & $-3.810^{3}$ & NS & $-3.010^{4}$ & NS \\
\hline Dead cells (\%) & -0.03 & NS & -0.23 & NS & -0.07 & NS & -0.45 & NS & -4.01 & NS \\
\hline Phagocytosis (\%) & -0.78 & NS & -1.3 & NS & -0.44 & NS & 0.96 & NS & 8.6 & NS \\
\hline PO activity (A.U.) & $7.710^{-5}$ & NS & $1.910^{-4}$ & NS & $1.210^{-5}$ & NS & $-6.410^{-6}$ & NS & $-2.510^{-4}$ & NS \\
\hline
\end{tabular}

A.U. $=$ arbitrary units $\left(\Delta \mathrm{DO}_{490 \mathrm{~nm}} \min ^{-1} \mathrm{mg}\right.$ protein $\left.^{-1}\right)$

Significance of the slope of the linear model:

NS: not significant ( $p$-value $>0.05) ; *$ : $p$-value $<0.05 ; * * p$-value $<0.01$ 
tors (Tab. 1). Temperature significantly and positively affected all hemocyte counts (THC, granulocyte and hyalinocyte counts, Tab. 1) and number of aggregates. The significance was higher for the granulocyte concentration, the correlation coefficient of the linear model was high $\left(r^{2}=0.62\right)$ and the correlation is clearly visible on Fig. 3. Salinity only affected granulocyte concentration (Tab. 1). Neverthless, salinity and temperature were correlated, only the effect of temperature was tested against hemocyte parameters (Tab. 1) because temperature was more correlated to THC and granulocytes than salinity. Food quantity (POM) and quality (POC and PON) had no significant effects on hemocyte parameters (Tab. 1). Hyalinocyte concentration, percentage of dead cells, phagocytosis percentage and PO activity were not correlated to any of the measured environmental factors (Tab. 1).

\subsection{Influence of endogenous factors on hemocyte parameters}

Effect of size/age Relationships between size/age (length) and hemocyte parameters were tested by the mean of linear models only in uninfected individuals (neither BRD-symptomatic and Perkinsus affected clams) to avoid effect of disease (Tab. 2). Although $r^{2}$ were low, all hemocyte counts (THC, granulocyte and hyalinocyte concentrations) significantly increased with size/age. The percentage of dead cells and the PO activity significantly decreased with size/age (Tab. 2).

Effect of sex and reproduction Effect of sex was tested during the reproduction period (end of April to end of September) when sex determination was possible. There were no significant differences between males and females in any of the hemocyte parameters ( $t$-test and Wilcoxon test ; $p$-values $>0.05$ ). Massive spawning generally occurs at the mid August/beginning of September in Gulf of Morbihan and result in a decrease of the condition index (Laruelle et al., 1994; Laruelle, 1999; Calvez, 2003). The decrease in the granulocyte concentration in the 2004Aug-03 and 2004-Sep-03 samples (Fig. 3) coincide with this period. Although condition index indicated that clams has spawned at the 16th sample (2005-Aug-24) the decrease of granulocyte count was not observed.

Condition index residuals In order to test if energetic status could be linked to hemocyte parameters independently of seasonal variations, relationships between condition index residuals and hemocyte parameters were tested using linear models (Tab. 2). There were significant positive relations between condition index residuals and all hemocyte counts but $r^{2}$ were very low $(<0.01)$. 
Table 2

Relationships between length and hemocyte parameters residuals in uninfected individuals and between condition index residuals and hemocyte parameters residuals (in uninfected and infected clams) tested using linear models.

\begin{tabular}{|c|c|c|c|c|c|c|}
\hline \multirow[t]{2}{*}{$\begin{array}{c}\text { Hemocyte parameter } \\
\text { residuals }\end{array}$} & \multicolumn{3}{|c|}{$\begin{array}{c}\text { Length } \\
\text { (uninfected clams) }\end{array}$} & \multicolumn{3}{|c|}{$\begin{array}{l}\text { Condition index residuals } \\
\text { (all clams) }\end{array}$} \\
\hline & slope & $r^{2}$ & $p$-value & slope & $r^{2}$ & $p$-value \\
\hline THC (cells $\mathrm{mL}^{-1}$ ) & $1.910^{4}$ & 0.034 & $* *$ & $4.210^{4}$ & 0.009 & $*$ \\
\hline Granulocytes (cells $\mathrm{mL}^{-1}$ ) & $1.210^{4}$ & 0.052 & $* *$ & $1.910^{4}$ & 0.006 & $*$ \\
\hline Hyalinocytes (cells mL ${ }^{-1}$ ) & $6.910^{3}$ & 0.010 & $* *$ & $2.410^{4}$ & 0.008 & $*$ \\
\hline Aggregates $\left(\mathrm{nb} \mathrm{mL}^{-1}\right)$ & $-1.510^{2}$ & 0.000 & NS & $-1.210^{3}$ & 0.004 & NS \\
\hline Dead cells (\%) & -0.07 & 0.017 & $* *$ & -0.03 & 0.000 & NS \\
\hline Phagocytosis (\%) & -0.08 & 0.001 & NS & -0.74 & 0.004 & NS \\
\hline PO activity (A.U.) & $-1.410^{-4}$ & 0.023 & $* *$ & $-1.410^{-4}$ & 0.002 & NS \\
\hline
\end{tabular}

A.U. $=$ arbitrary units $\left(\Delta \mathrm{DO}_{490 \mathrm{~nm}} \min ^{-1} \mathrm{mg}\right.$ protein $\left.{ }^{-1}\right)$

Significance of the slope of the linear model:

NS: $p$-value $>0.05 ; *: p$-value $<0.05 ; * * p$-value $<0.01$

\subsection{Diseases}

\subsubsection{Prevalences of BRD symptoms and perkinsosis}

BRD prevalence was low (Fig. 4 A.; average prevalence: 9.7\%) and showed no significant variation during the sampling period $\left(\chi^{2}=12.96, d f=16, p\right.$-value $=$ 0.675), disease intensity was also low: $90 \%$ of the symptomatic clams had a CDS lower than 4 on a scale going from 0 to 7 .

Perkinsosis prevalence was moderated (Fig. 4 A.; $20-50 \%$ average prevalence: $38.2 \%)$. Although variations in prevalence during the sampling period were significant $\left(\chi^{2}=37.79 ; d f=16 ; p\right.$-value $\left.=2.10^{-3}\right)$ no clear seasonal pattern appeared. Perkinsus sp. infection intensity ranged between 0 and $1.6310^{6}$ cells/g gill WW, with a mean of $1.9610^{4}$. Perkinsus sp. prevalence and infection intensity were not correlated to temperature (linear models, $p$-value $=0.902$ and 0.979 for prevalence and infection intensity, respectively).

There were significant positive correlations between size and both BRD (Fig. 4 B.) and perkinsosis prevalences (Fig. 4 C.) 

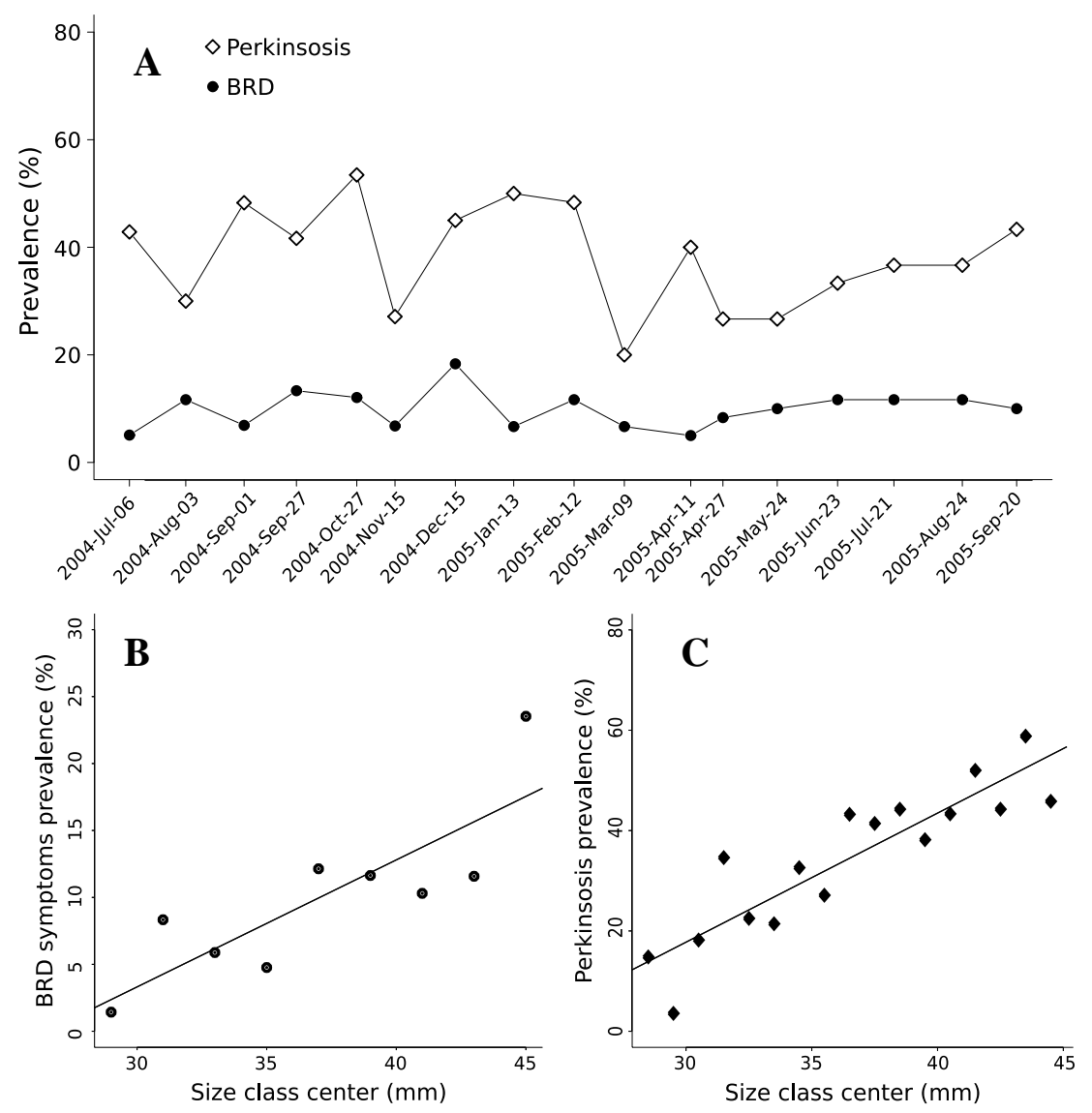

Fig. 4. A: Evolution of prevalence of perkinsosis and BRD during the sampling period; B: Relationship between center of the size classes and BRD symptom prevalence $\left(y=0.94 x-0.25 ; r^{2}=0.52 ; p\right.$-value $\left.=0.005\right) ; \mathrm{C}$ : Relationship between center of the size classes and perkinsosis prevalence $\left(y=2.57 x-59 ; r^{2}=0.77 ; p\right.$-value $\left.=1.8310^{-6}\right)$

\subsection{Influence of diseases on hemocyte parameters}

There were no difference in any measured hemocyte parameter residuals between BRD-asymptomatic clams and symptomatic clams ( $p$-values $>0.05)$, neither between BRD-asymptomatic clams and clams with CDS $=3$ and higher ( $p$-values > $0.05)$. No significant relationship between condition index residuals and BRD stage was found (linear model, $p$-value $=0.211$ ).

Effect of perkinsosis could only be detected (Fig. 5) when comparing uninfected clams with highly infected clams (>100 000 Perkinsus sp. cell/g gill WW). Perkinsus sp. significantly increased granulocyte concentration and THC and significantly decreased the phagocytosis percentage (Fig. 5). No effect of Perkinsus sp. infection was observed on hyalinocyte concentration, number of aggregates ( $t$-test, $p$ value > 0.05 ), dead cells percentage ( $t$-test, $p$ value $>0.05$ ) and PO activity (Wilcoxon Test, $p$-value $>0.05)$. 

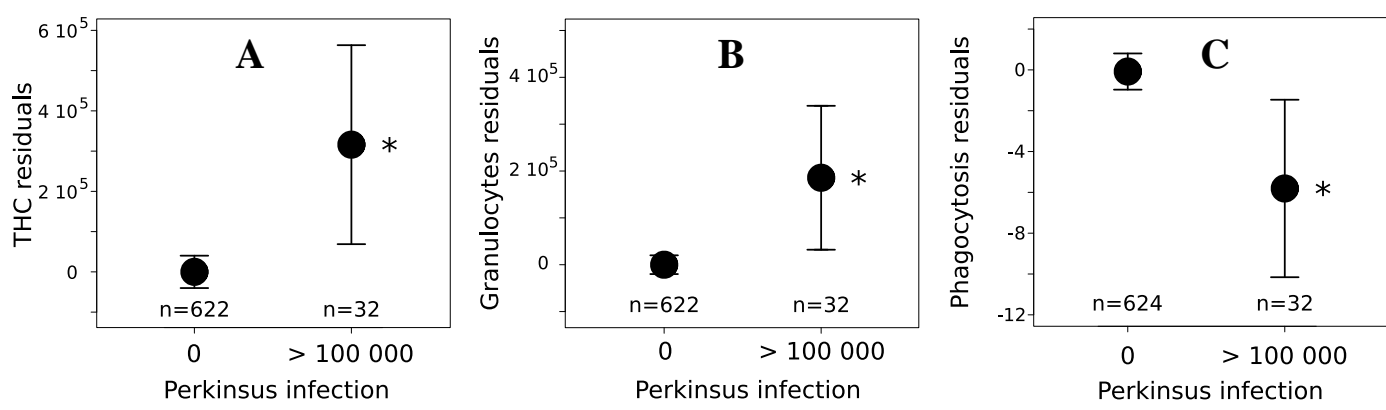

Fig. 5. Comparisons of A: Total hemocyte count, B: Granulocyte count, C: Phagocytosis percentage between uninfected individuals (0 Perkinsus sp. cell/g gill WW; i.e. under the detection threshold) and highly infected individuals (> 100000 Perkinsus sp. cell/g gill WW). Results are expressed as mean $\pm 95 \%$ confidence interval. The stars $(*)$ indicates significant differences $(p$-value $<0.05)$.

\subsection{Overall variability of hemocyte parameters}

Contributions of the environmental condition, internal factors and diseases to overall variability of four hemocyte parameters (THC, granulocyte and hyalinocyte concentration, phagocytosis) were investigated by the mean of a MANOVA (Tab. 3), only factors that had a significant effect on these hemocyte parameters were included. Results indicate that the most explained hemocyte parameter was the granulocyte concentration (Tab. 3) for which only $16.4 \%$ of the variability was explained by temperature $(11.3 \%)$, length $(4.1 \%)$, Perkinsus sp. infection $(0.6 \%)$ and condition index residuals $(0.4 \%)$. Only $10 \%$ of the THC variability was explained by these factors. Factors explaining most of the variance of the hemocyte parameters were temperature and length. Perkinsus sp. only explained very little of the overall variability of the hemocyte system : its effects are significant when comparing uninfected to heavily infected clams (Fig. 5) but no significant trend could be detected when using continuous linear model of THC or phagocytosis against concentration of Perkinsus sp.

\section{Discussion}

The aim of this study was to better understand the relative effect of environmental and internal factors and diseases on hemocyte parameters in the field. Independent effect of each factor on the hemocyte parameters will first be discussed. The combined effect of measured factors to the overall variability of hemocyte will finally be discussed. 
Table 3. Summary of the weights of environmental factor (temperature) and internal factors (size/age and condition index residuals) and Perkinsus sp. infection on the total variability of THC, granulocyte concentration (cell mL${ }^{-1}$ ), hyalinocyte concentration (cell $\mathrm{mL}^{-1}$ ) and phagocytosis percentage computed from a MANOVA. Factors that had no significant effect were not included for computations. Partial $r^{2}$ values indicate the weight of each factor on the total variability of each parameter, $\mathrm{r}^{2}$ indicate the weight of all included factor on the total variability of each parameter.

\begin{tabular}{|c|c|c|c|c|c|c|c|c|}
\hline \multirow[b]{2}{*}{ Factor } & \multicolumn{2}{|c|}{ THC } & \multicolumn{2}{|c|}{ Granulocyte conc. } & \multicolumn{2}{|c|}{ Hyalinocyte conc. } & \multicolumn{2}{|c|}{ Phagocytosis } \\
\hline & partial $r^{2}$ & $p$-value & partial $r^{2}$ & $p$-value & partial $r^{2}$ & $p$-value & partial $r^{2}$ & $p$-value \\
\hline Temperature & 0.033 & $* *$ & 0.113 & $* *$ & \multicolumn{2}{|c|}{ NI } & \multicolumn{2}{|c|}{ NI } \\
\hline Length & 0.055 & $* *$ & 0.041 & $* *$ & 0.030 & $* *$ & 0.028 & $* *$ \\
\hline CI residuals & 0.009 & $* *$ & 0.004 & $*$ & 0.009 & $* *$ & \multicolumn{2}{|c|}{ NI } \\
\hline Perkinsus sp. & 0.003 & NS & 0.006 & $* *$ & \multicolumn{2}{|c|}{ NI } & $2.410^{-5}$ & NS \\
\hline & $\mathrm{r}^{2}$ & $p$-value & $\mathrm{r}^{2}$ & $p$-value & $\mathrm{r}^{2}$ & $p$-value & $\mathrm{r}^{2}$ & $p$-value \\
\hline All factors & 0.100 & $* *$ & 0.164 & $* *$ & 0.039 & $* *$ & 0.028 & $* *$ \\
\hline
\end{tabular}

CI: condition index

NI: not included in MANOVA

NS: $\quad$ not significant $(p$-value $>0.05) ; *$ : $p$-value $<0.05 ; * * p$-value $<0.01$ 


\subsection{Effect of environmental factors on hemocyte parameters}

Temperature was the major environmental factor modulating hemocyte parameters. There were positive correlation between temperature and both granulocyte and total hemocyte counts. Since the slopes of the linear models relating temperature with granulocyte concentration and THC are equal (Tab. 1) it is possible to conclude that the increase in THC simply reflects the increase in granulocyte concentration. Several laboratory experiments emphasized the positive effect of temperature on hemocyte concentration in hemolymph in various bivalve and crustacean species (see e.g. Truscott and White, 1990; Chu and La Peyre, 1993; Fisher et al., 1996; Chu, 1998; Liu et al., 2004; Paillard et al., 2004; Monari et al., 2007), few studies however showed the occurrence of this pattern in the field (Fisher et al., 1996; Carballal et al., 1998; Soudant et al., 2004). The increase of circulating hemocyte count is generally considered as a consequence of proliferation or movement of cells from tissue into hemolymph (Pipe and Coles, 1995). Thus, an increase of the hemocyte proliferation with temperature could explain the observed pattern. Number of hemocyte aggregates was also positively correlated to temperature. Hemocyte aggregation is presumed to be involved in hemostasis and wound healing (Chen and Bayne, 1995) but also in defence mechanisms (Tiscar and Mosca, 2004). Formation of hemocyte aggregates is the result of the adhesion activity of hemocytes (Chen and Bayne, 1995; Auffret and Oubella, 1997). Since bivalves are poikilotherms, hemocyte activity may scale with temperature thus explaining the correlation between aggregate concentration and temperature.

Extreme (high and low) salinities have been shown to induce variations of total hemocyte counts in several bivalve species (Chu and La Peyre, 1991; Reid et al., 2003; Matozzo et al., 2007), but generally variation of salinity within the life range of the species does not affect hemocyte counts (Matozzo et al., 2007). This tend to confirm that, in this study, the observed correlation between salinity and granulocyte concentration is only attributable to the correlation between temperature and salinity.

Although phagocytosis significantly varied during the studied period, this parameter does not seem to be affected by any of the measured environmental factors. This result appears contradictory with laboratory experiments which showed that phagocytosis varied with temperature (Chu and La Peyre, 1993; Allam et al., 2002b; Monari et al., 2007) and salinity (Reid et al., 2003). The reasons for this difference remains unclear but this emphasizes the difficulty in extending laboratory results to the field.

Low food levels and starvation have been shown to reduce THC in oysters (Delaporte et al., 2006; Butt et al., 2007). However, in an earlier study, Ashton-Alcox and Ford (1998) showed that a 4-week starvation did not affect hemocyte counts in oysters. This result suggest that this period is not long enough to induce a starvation 
stress. In our study, indicators of food quantity (POM) and quality (POC, PON) did not appeared to affect any of the measured hemocyte parameters. This suggest that in such natural conditions food level and quality were not low enough to induce any modification of hemocyte parameters during the studied period.

The poor relationships between other environmental factors and hemocyte parameters emphasize the difficulty to assess the environmental control of hemocyte system in the field.

\subsection{Effect of endogenous variables}

Size/age Variability of hemocyte parameters with size/age have been little studied (Carballal et al., 1997; Lopez et al., 1997; Carballal et al., 1998; Barracco et al., 1999) and a clear effect of size on the hemocyte parameters was rarely found. Only Carballal et al. (1998) found a significant increase in number of circulating granulocytes with age in Mytilus galloprovincialis. In most of the above studies, the size ranges were smaller than in our study (this study: $200 \%$ of difference between the smallest and the largest individuals and $127 \%$ to $150 \%$ in Lopez et al., 1997; Carballal et al., 1998; Barracco et al., 1999, studies). Furthermore, the large number of individuals sampled in our study allowed to distinguish the effect of size/age within the large variability of the hemocyte parameters. Our study emphasizes that, in the Manila clam, total hemocyte, granulocyte and hyalinocyte counts are significantly positively correlated to size while phagocytosis and dead cells percentage are negatively correlated to size.

Sex and reproduction Links between gender and hemocyte system have poorly been studied (Barracco et al., 1999; Gagné et al., 2007). In both studies, as in the present one, results tend to show that hemocyte parameters are independent of gender. Such relationships may not be expected since hemocyte systems plays an important role in maintaining organism homeostasis. Such requirement may not vary with gender.

However, gonadal cycle can influence the hemocyte system (see Oliver and Fisher, 1999, for a review), in a laboratory experiment Delaporte et al. (2006) observed that THC decreased during gametogenesis in the oyster Crassotrea gigas. Field studies showed that THC decrease during spawning period (in Mytilus galloprovincialis and Crassostrea virginica, Pipe et al., 1995; Fisher et al., 1996) presumably because of hemocyte infiltration in gonadal tissue. In our study, condition index profile indicated that clams had already spawned on the 2004-sep-01 and 2005aug-24; these events could not be associated to a decrease in THC or any other of the measured parameters. 
Condition index residuals Condition index residuals provide a rough information about the energetic status independently of seasonal variation (i.e. is the individual more or less fat for the season?). Our study shows that there is a little positive effect, but nonetheless significant, of condition index residuals on hemocyte counts. This tends to confirm the hypothesis of Ashton-Alcox and Ford (1998) who suggested that variability of molluscan hemocyte parameters could be linked to the amount of stored energy reserves to explain the high observed inter-individual variations. This relationship could be explained by the involvement of hemocytes in nutrient mobilisation (Cheng, 1996). Nevertheless, the relationship only explains little of the total variability of hemocyte parameters.

\subsection{Diseases}

Prevalence and intensity of perkinsosis and BRD Prevalence of Perkinsus sp. infection was moderated and ranged between 20 and 50\% (average 38.2\%) which is comparable to the values reported by by Ngo and Choi (2004) in R. philippinarum and $R$. decussatus beds of Jeju (Korea) and Portugal (Ngo and Choi, 2004; Leite et al., 2004). These prevalences are lower than those reported by Park and Choi (2001) in various places of Korea where prevalence reached $100 \%$ in some locations and by Villalba et al. (2005) in natural $R$. decussatus beds of Galicia (Spain), where prevalence ranged between 45 and $100 \%$. Although perkinsosis prevalence showed significant variation during the study period, no clear annual pattern appeared. Epizootiology studies showed that Perkinsus marinus infection in the oyster Crassostrea virginica prevalence is closely related to temperature and salinity (see review in Villalba et al., 2004) which results in an increased prevalence in summer. Surveys of $P$. olseni infections in Ruditapes decussatus and $R$. philippinarum showed an annual pattern with an increase of prevalence in autumn and/or spring (Villalba et al., 2005; Ngo and Choi, 2004). These studies contrast with our results. Nevertheless, Leite et al. (2004) did not found any annual pattern of Perkinsus sp. in $R$. decussatus along the Portugese coasts during their 2-year survey which shows that seasonal pattern is not always observed in P. olseni infection prevalence.

Estimation of Perkinsus sp. burden in gill (cells/g gill WW) provide an over-estimation of the total body burden (cells/g flesh WW) (Choi et al., 2002). In our study Perkinsus sp. infection intensity was low (average: $210^{4}$ cells/g gill WW) and our values are consistent with the values obtained by Lassalle et al. (2007) in Gulf of Morbihan. Higher values have been reported in location more southern along the French Atlantic coast : more than $810^{4}$ cells/g gill WW in Arcachon bay (Lassalle et al., 2007). Higher values were also reported in Korea (up to $8.710^{6}$ cells/g flesh WW; Park and Choi, 2001), in Japan $\left(2.2510^{6}\right.$ cells/g flesh WW; Ishaya bay; Choi et al., 2002) and in Spain $\left(\simeq 510^{4}\right.$ cells/g flesh WW in $R$. decussatus from Galicia; Villalba et al., 2005). 
Average prevalence of BRD symptoms during the study period (9.7\%) was low in comparison to the prevalences observed in aquaculture clams beds of Northern Brittanny (Brouennou, Finistère, France) that ranged between 33 and 100\% (Paillard, 1992; Paillard et al., 1997; Paillard, 2004a). Our results are in accordance with previous studies performed in natural populations of Gulf of Morbihan (Paillard, 2004a; Lassalle et al., 2007) that found prevalences between 4 and $30 \%$. However, no annual pattern in BRD prevalence was found and this contrasts with the field surveys of Paillard et al. (1997) and Paillard (2004a). These studies showed that symptomatic clams are found during all the year, but generally BRD symptoms prevalence increases toward the beginning of the spring and decreases towards the beginning of the summer. Low temperatures during the rising phase of prevalence have been invoked to explain this pattern (Paillard et al., 1997, 2004; Paillard, 2004a,b). The lack of pattern observed in our study may be explained by the low prevalence and intensity of BRD during the studied period : $80 \%$ of the symptomatic clams had a CDS of 3 or less, stage at which the extend of the brown deposit is localised to small area of the inner shell (Paillard and Maes, 1994))

Size-prevalence relationships The positive relationships between size and prevalence for both diseases correspond to the general pattern observed for most parasites in filter feeder bivalves (Guralnick et al., 2004). This pattern has already been shown for the P. marinus/C. virginica (Andrews and Hewatt, 1957) and P. olseni/R. decussatus interactions (Villalba et al., 2005). The explanation of such a pattern lies in both an increased filtration rate in biggest individuals and an accumulation of the parasite during life span, these processes leading to an increase of prevalence and infection intensity with size (Andrews and Hewatt, 1957; Guralnick et al., 2004; Villalba et al., 2005). Nevertheless, another interpretation for the size-BRD prevalence relationship have been given in Flye-Sainte-Marie et al. (2008): increased body surface area with size could lead to higher probability of contact with big sediment grains that may induce disruptions and subsequently a potential entry for the pathogen $V$. tapetis.

Relations between hemocyte parameters and diseases High Perkinsus sp. infection significantly increased granulocyte concentration and consequently THC in highly infected individuals (> 100000 Perkinsus sp. cells/g gill WW). This result is contradictory with those of Ordás et al. (2000) who found a decrease of THC in $R$. decussatus infected by $P$. olseni. Nevertheless, augmentation of circulating hemocytes have been widely documented in $C$. virginica heavily infected by $P$. marinus (see e.g. Anderson et al., 1992; Chu and La Peyre, 1993; Anderson et al., 1995; La Peyre et al., 1995; Anderson et al., 1996). These authors suggest that this increase reflects a mobilisation/production of hemocytes to counteract Perkinsus sp. development. In our study, high $P$. olseni infection also significantly reduced hemocyte phagocytosis percentage which is in accordance with previous studies who showed an inability of $R$. decussatus hemocyte to phagocyte $P$. olseni zoospores 
(Lopez et al., 1997) and a decrease in percentage of phagocytosis in P. olseniinfected $R$. decussatus (Ordás et al., 2000). Although Muñoz et al. (2006) showed an increase in the PO activity in $R$. decussatus lowly and moderately infected by $P$. olseni, no significant effect of Perkinsus sp. on this parameter could be found from our data.

In this study, BRD had no significant influence on any of the hemocyte parameters. These results contrast with previous experimental studies which showed that (1) V. tapetis inoculation induces an increase in THC (Paillard et al., 1994; Allam et al., 2000, 2006; Paillard, 2004b), (2) a decrease in phagocytic activity (Allam et al., 2002b; Allam and Ford, 2006), and (3) an increase of dead cell percentage (Allam et al., 2000; Allam and Ford, 2006; Allam et al., 2006). Symptoms of $\mathrm{BRD}$ results of the interaction between the bacteria and the clam over time. Experimental infection may uncouple bacterial burden and symptoms (brown deposit). In these conditions, effect on hemocyte system may be detected before apparition of symptoms. Thus, discrepancy between the above experimental observations and our results may be explained by the low natural infection intensity, presumably associated to a low V. tapetis burden. Consistently with our study, Reid et al. (2003) experimental work failed to find any significant effect of BRD on PO activity.

Allam et al. (2001) experimental study suggested that higher granulocyte concentration may be related to a higher resistance to BRD. Interestingly, in our study, granulocyte concentration significantly varied but BRD prevalence was not lower when granulocyte concentration was high. Granulocyte concentration significantly increased with size/age but prevalence and size were also correlated. Thus, it was not possible to link a high granulocyte concentration with any variation of BRD prevalence. This observation is consistent with Reid et al. (2003) who indicated that increased hemocyte population did not appear to have a direct role in reducing BRD levels. This suggests that association of resistance to BRD and hemocyte parameters is not straightforward.

Diseases and condition index Low infection intensities of both diseases observed during the studied period explains that condition index was not affected in infected individuals. These results are consistent with previous studies indicating that both diseases are susceptible to interfere with energy balance and to affect condition index (Leite et al., 2004; Park et al., 2006; Flye-Sainte-Marie et al., 2007b) only at high infection intensities.

\subsection{Variability of hemocyte parameters in the field}

Consistently with previous studies, this multiparametric field study emphasizes that part of the variability of the hemocyte system of bivalves is attributable to en- 
vironmental and internal factors as well as diseases. Temperature was the only environmental factor explaining seasonal variations of some of the hemocyte parameters and contributed to $10 \%$ of the variability of granulocyte concentration. Effect of size/age on hemocyte parameters have been poorly described in literature (Carballal et al., 1997; Lopez et al., 1997; Carballal et al., 1998; Barracco et al., 1999). It was nevertheless the factor both affecting most of the measured hemocyte parameters and significantly contributing to the explanation of the variability of hemocyte system. Interestingly, although links between disease and hemocyte system has been extensively described in the literature these links were little confirmed in our study. In accordance with Adamo (2004), this study emphasizes that the measures of hemocyte parameters cannot directly be interpreted as measurement of immunocompetence (i.e. capacity of defence against a pathogen).

Although this study identified factors that significantly affected the hemocyte system, these factors only explained little of the overall variability of the hemocyte parameters. For the mostly explained parameter (granulocyte concentration) only $16.4 \%$ of the variance could be explained from the measured factors. Part of the unexplained variability can be attributed to unexplained month to month variations, suggesting that other environmental factors than temperature, salinity or trophic resource may modulate the hemocyte system. Effect of contaminants and toxic algae on hemocyte system of bivalves have been described in literature (see e.g. Oliver et al., 2001; Auffret et al., 2004, 2006; Hégaret and Wikfors, 2005b,a; Hégaret et al., 2007) and could explain these month to month variations. Most of the variability of the hemocyte system could be attributed to inter-individual differences and thus could not be associated with any parameter that we measured. AshtonAlcox and Ford (1998) suggested that variability in molluscan hemocytes could be more immediately linked to individual metabolic condition than to an inability to buffer hemolymph against external ambient conditions. In the past 30 years, many authors have studied the link between hemocyte system and disease and thus tending to reduce the role of hemocyte system to immune functions. Nevertheless, although poorly documented, there are evidences of implication of hemocyte system in various other functions such as nutrition, wound repair, inflamation (Fisher, 1986; Cheng, 1996) and shell reparation and mineralization (Fisher, 1986, 2004; Mount et al., 2004). This study emphasizes the need for a better understanding of the various functions of the hemocyte system and how does the requirements of these functions control the hemocyte system. Such a knowledge is necessary to better understand the linkages between environment, bivalve metabolic status, hemocyte system and disease development, and to use of bivalve hemocyte parameters as environmental biomarkers. 


\section{Acknowledgements}

This work was founded by Région Bretagne within the MODELMAB regional research program. The authors greatly thank Lionel Allano for his technical help during field sampling. The authors thanks Jean-Francois Bouget from IFREMER la Trinité-sur-mer for fournishing salinity data. The authors thank Antoine Emery, Pierre Huonnic, Alain Lemercier, Morgane Lejart, Mirella da Silva, Sorcha Ni'Longphuirt, Brivaela Moriceau, Pierre Fouillaron, Anne-Laure Cassonne, Angéline Frantz, Charlotte Dentan and Emmanuelle Ferret for their help for field sampling and analyses. The author also thank Annick Masson for CHN analysis.

\section{References}

Adamo, S. A., 2004. How sould behavioural ecologists interpret measurements of immunity? Animal behaviour 68, 1443-1449.

Allam, B., Ashon-Alcox, K. A., Ford, S. E., 2001. Haemocyte parameters associated with resistance to brown ring disease in Ruditapes spp. clams. Developmental and Comparative Immunology 25, 365-375.

Allam, B., Ashton-Alcox, K. A., Ford, S. E., 2002a. Flow cytometric comparison of haemocytes from three species of bivalve molluscs. Fish Shellfish Immunol. $13(2), 141-158$.

Allam, B., Ashton-Alcox, K. A., Ford, S. E., 2002b. Flow cytometric measurement of hemocyte viability and phagocytic activity in the clam, Ruditapes philippinarum. J. Shellfish. Res. 21, 13-19.

Allam, B., Ford, S. E., 2006. Effects of the pathogenic Vibrio tapetis on defence factors of susceptible and non-susceptible bivalve species: I. Haemocyte changes following in vitro challenge. Fish Shellfish Immunol. 20, 374-383.

Allam, B., Paillard, C., Auffret, M., 2000. Alterations in haemolymph and extrapallial fluid parameters in the Manila clam, Ruditapes philippinarum, challenged with the pathogen Vibrio tapetis. J. Invertebr. Pathol. 76, 63-69.

Allam, B., Paillard, C., Auffret, M., Ford, S. E., 2006. Effects of the pathogenic Vibrio tapetis on defence factors of susceptible and non-susceptible bivalve species: II. Cellular and biochemical changes following in vivo challenge. Fish Shellfish Immunol. 20, 384-397.

Anderson, R. S., Burreson, E. M., Paynter, K. T., 1995. Defense responses of hemocytes withdrawn from Crassostrea virginica infected with Perkinsus marinus. J. Invertebr. Pathol. 66 (1), 82-89.

Anderson, R. S., Paynter, K. T., Burreson, E. M., 1992. Increased reactive oxygen intermediate production by hemocytes withdrawn from Crassostrea virginica infected with Perkinsus marinus. Biolgical Bull. 183 (3), 476-481.

Anderson, R. S., Unger, M. A., Burreson, E. M., 1996. Enhancement of Perkin- 
sus marinus disease progression in TBT-exposed oysters (Crassostrea virginica). Mar. Envir. Res. 42 (1), 177-180.

Andrews, J. D., Hewatt, W. G., 1957. Oyster mortality studies in Virginia. II. the fungus disease caused by Dermocystidium marinum in oysters of Chesapeake Bay. Ecol. Monogr. 27 (1), 1.264.

Ashton-Alcox, K. A., Ford, S. E., 1998. Variability in molluscan hemocytes: a flow cytometric study. Tissue and Cell 30 (2), 195-204.

Auffret, M., Duchemin, M., Rousseau, S., Boutet, I., Tanguy, A., Moraga, D., Marhic, A., 2004. Monitoring of immunotoxic responses in oysters reared in areas contaminated by the" Erika" oil spill. Aquat. Living Resour. 17 (3), 297302.

Auffret, M., Oubella, R., 1994. Cytometric parameters of bivalve molluscs: effect of environmental factors. In: Stolen, J.S., Fletcher, T.C. (Eds.), Modulators of Fish Immune Response. SOS publication, Fair Haven, NJ, USA, 23-32.

Auffret, M., Oubella, R., 1997. Hemocyte aggregation in the oyster Crassostrea gigas: In vitro measurement and experimental modulation by xenobiotics. Comp. Biochem. Physiol. A 118 (3), 705-712.

Auffret, M., Rousseau, S., Boutet, I., Tanguy, A., Baron, J., Moraga, D., Duchemin, M., 2006. A multiparametric approach for monitoring immunotoxic responses in mussels from contaminated sites in Western Mediterranea. Ecotox. Env. Safty 63, 393-405.

Barracco, M. A., Medeiros, I. D., Moreira, F. L. M., 1999. Some haematoimmunological parameters in the mussel Perna perna. Fish Shellfish Immunol. 9 (5), 387-404.

Borrego, J. J., Castro, D., Luque, A., Paillard, C., Maes, P., Gracia, M., Ventosa, A., 1996. Vibrio tapetis sp. nov., the causative agent of the brown ring disease affecting cultured clams. Int. J. Syst. Bacteriol. B 46, 480-484.

Butt, D., Aladaileh, S., O'Connor, W. A., Ratios, D. A., 2007. Effect of starvation on biological factors related to immunological defence in the Sydney rock oyster (Saccostrea glomerata). Aquaculture 264 (1-4), 82-91.

Calvez, I., 2003. Approche de la variabilité spatiale d'une population de palourdes Ruditapes philippinarum (Adams et Reeve), aux stades larvaires et postlarvaires. Thèse de Doctorat, Université de Bretagne Occidentale, Brest.

Carballal, M., Villalba, A., López, C., 1998. Seasonal variation and effects of age, food availability, size, gonadal development, and parasitism on the hemogram of Mytilus galloprovincialis. J. Invertebr. Pathol. 72 (3), 304-312.

Carballal, M. J., Lopez, C., Azevedo, C., Villalba, A., 1997. In vitro study of phagocytic ability of Mytilus galloprovincialis Lmk. haemocytes. Fish Shellfish Immunol. 7 (6), 403-416.

Castro, D., Martinez-Manzanares, E., Luque, A., Fouz, B., Morinigo, M., Borrego, J. J., Toranzo, A. E., 1992. Characterization of strains related to brown ring disease outbreaks in southwestern spain. Dis. Aquat. Org. 14, 229-236.

Chen, J. H., Bayne, C. J., 1995. Bivalve mollusc hemocyte behaviors: Characterization of hemocyte aggregation and adhesion and their inhibition in the california mussel (Mytilus californianus). Biolgical Bull. 188 (3), 255-266. 
Cheng, T. C., 1996. Hemocytes: forms and functions. In: Kennedy, V. S., Newell, R. I. E., Eble, F. (Eds.), The eastern oyster Crassostrea virginica. Maryland Sea Grant College, pp. 299-333.

Choi, K., Park, K., Lee, K., Matsuoka, K., 2002. Infection intensity, prevalence, and histopathology of Perkinsus sp. in the Manila clam, Ruditapes philippinarum, in Isahaya bay, Japan. J. Shellfish. Res. 21 (1), 119-126.

Choi, K.-S., Wilason, E. A., Lewis, D. H., Powell, E. N., Ray, S. M., 1989. The energetic cost of Perkinsus marinus parasitism in oysters: quantification of the thioglycollate method. J. Shellfish. Res. 8, 125-131.

Chu, F.-L. E., 1998. Host defenses against Perkinsus marinus: a review of recent findings in the eastern oyster, Crassostrea virginica. J. Shellfish. Res. 18 (1), 321-322.

Chu, F.-L. E., 2000. Defence mechanism of marine bivalves. In: Fingerman, M., Nagabhushanam, R. (Eds.), Recent advances in Biotechnology. Volume 5 Immunobiology and pathology. Science publishers, Inc., pp. 1-42.

Chu, F.-L. E., La Peyre, J. F., 1991. Effect of salinity on Perkinsus marinus susceptibility and defense-related activities in eastern oysters, Crassostrea virginica. J. Shellfish. Res. 10, 294.

Chu, F.-L. E., La Peyre, J. F., 1993. Perkinsus marinus susceptibility and defenserelated activities in eastern oysters Crassostrea virginica: temperature effects. Dis. Aquat. Org. 16 (3), 223-234.

Delaporte, M., Soudant, P., Lambert, C., Moal, J., Pouvreau, S., Samain, J.-F., 2006. Impact of food availability on the energy storage and defense related hemocyte of the Pacific oyster Crassostrea gigas during an experimental reproductive cycle. Aquaculture 254, 571-582.

Delaporte, M., Soudant, P., Moal, J., Lambert, C., Quéré, C., Miner, P., Choquet, G., Paillard, C., Samain, J.-F., 2003. Effect of a mono-specific algal diet on immune functions in two bivalves species, Crassostrea virginica and Ruditapes philippinarum. J. Exp. Biol. 206 (17), 3053-3064.

Fisher, W. S., 1986. Structure and function of oyster hemocytes. In: Brehelin, M. (Ed.), Immunity in invertebrates, cells, molecules and defense reactions. Springer, Berlin, pp. 25-35.

Fisher, W. S., 2004. Relationship of amaebocytes and terrestrial elements to adult shell deposition in eastern oysters. J. Shellfish. Res. 23, 353-367.

Fisher, W. S., Oliver, L. M., Edwards, P., 1996. Hematologic and serologic variability of eastern oysters from Apalachicola Bay, Florida. J. Shellfish. Res. 15, 555-564.

Flassch, J. P., Leborgne, Y., 1992. Introduction in Europe, from 1972 to 1980, of the Japanese Manila clam (Tapes philippinarum) and effects on aquaculture production and natural settlement. ICES Marine Symposium 194, 92-96.

Flye-Sainte-Marie, J., Jean, F., Ford, S. E., Paillard, C., 2008. Effect of sediment grain-size on development of brown ring disease in the Manila clam Ruditapes philippinarum. Aquaculture 278, 184-187.

Flye-Sainte-Marie, J., Jean, F., Paillard, C., Ford, S., Powell, E., Hofmann, E., Klinck, J., 2007a. Ecophysiological dynamic model of individual growth of $R u$ - 
ditapes philippinarum. Aquaculture 266, 130-143.

Flye-Sainte-Marie, J., Pouvreau, S., Paillard, C., Jean, F., 2007b. Impact of Brown Ring Disease on the energy budget of the Manila clam Ruditapes philippinarum. J. Exp. Mar. Biol. Ecol. 349 (2), 378-389.

Ford, S. E., Paillard, C., 2007. Repeated sampling of individual bivalve mollusks I: Intraindividual variability and consequences for haemolymph constituents of the Manila clam, Ruditapes philippinarum. Fish Shellfish Immunol. 23, 280-291.

Gagné, F., Blaise, C., Pellerin, J., Fournier, M., Durand, M. J., Talbot, A., 2007. Relationships between intertidal clam population and health status of the soft-shell clam Mya arenaria in the St. Lawrence Estuary and Saguenay Fjord (Québec, Canada). Environ. Int. , in press.

Guralnick, R., Hall, E., Perkins, S., 2004. A comparative approach to understanding causes and consequences of mollusc-digenean size relationships: A case study with allocreadiid trematodes and Cyclocalyx clams. J. Parasitol. 90 (6), 12531262.

Hégaret, H., da Silva, P. M., Wikfors, G. H., Lambert, C., De Bettignies, T., Shumway, S. E., Soudant, P., 2007. Hemocyte responses of manila clams, $R u$ ditapes philippinarum, with varying parasite, Perkinsus olseni, severity to toxicalgal exposures. Aquat. Toxicol. 84 (4), 469-479.

Hégaret, H., Wikfors, G. H., 2005a. Effects of natural and field-simulated blooms of the dinoflagellate Prorocentrum minimum upon hemocytes of eastern oysters, Crassostrea virginica, from two different populations. Harmful Algae 4 (2), 201209.

Hégaret, H., Wikfors, G. H., 2005b. Time-dependent changes in hemocytes of eastern oysters, Crassostrea virginica, and northern bay scallops, Argopecten irradians irradians, exposed to a cultured strain of Prorocentrum minimum. Harmful Algae 4 (2), 187-199.

Humphreys, J., Caldow, R. W. G., McGrorty, S., West, A. D., Jensen, A. C., 2007. Population dynamics of naturalised Manila clams Ruditapes philippinarum in British coastal waters. Mar. Biol. 151, 2255-2270.

Jensen, A. C., Humphreys, J., Caldow, R. W. G., Grisley, C., Dyrynda, P. E. J., 2004. Naturalization of the Manila clam (Tapes philippinarum), an alien species, and establishment of a clam fishery within Poole Harbour, Dorset. J. Mar. Biol. Assoc. 84 (05), 1069-1073.

La Peyre, J. F., Chu, F.-L. E., Meyers, J. M., 1995. Haemocytic and humoral activities of eastern and pacific oysters following challenge by the protozoan Perkinsus marinus. Fish Shellfish Immunol. 5, 179-190.

Labreuche, Y., Soudant, P., Gonçalvez, M., Lambert, C., Nicolas, J.-L., 2006. Effects of extracellular products from the pathogenic Vibrio aesturianus strain 01/32 on the lethality and cellular immune responses of the oyster Crassostrea gigas. Developmental and Comparative Immunology 30, 367-379.

Laruelle, F., 1999. Phénologie et déterminisme de la reproduction chez Ruditapes decussatus (L.) and Ruditapes philippinarum (Adams and Reeve) en Bretagne. Thèse de Doctorat, Université de Bretagne Occidentale, Brest.

Laruelle, F., Guillou, J., Paulet, Y., 1994. Reproductive pattern of the clams, Rudi- 
tapes decussatus and Ruditapes philippinarum, on intertidal flats in Brittany. J. Mar. Biol. Assoc. 172, 69-96.

Lassalle, G., de Montaudouin, X., Soudant, P., Paillard, C., 2007. Parasite coinfection of two sympatric bivalves, the Manila clam (Ruditapes philippinarum) and the cockle (Cerastoderma edule) along a latitudinal gradient. Aquat. Living Resour. 20, 33-42.

Leite, R. B., Afonso, R., Cancela, M. L., 2004. Perkinsus sp. infestation in carpetshell clams, Ruditapes decussatus (L), along the Portuguese coast. Results from a 2-year survey. Aquaculture 240, 39-53.

Liu, S., Jiang, X., Hu, X., Gong, J., Hwang, H., Mai, K., 2004. Effects of temperature on non-specific immune parameters in two scallop species: Argopecten irradians (Lamarck 1819) and Chlamys farreri (Jones \& Preston 1904). Aquacult. Res. 35 (7), 678-682.

Lopez, C., Carballal, M. J., Azevedo, C., Villalba, A., 1997. Differential phagocytic ability of the circulating haemocyte types of the carpet shell clam Ruditapes decussatus (Mollusca: Bivalvia). Dis. Aquat. Org. 30 (3), 209-215.

Marie, D., Partensky, F., Vaulot, D., Brussaard, C., 1999. Enumeration of phytoplankton, bacteria and viruses in marine samples. Curr. Protocols Cytom 11, 115.

Marin, M. G., Moschino, V., Deppieri, M., Lucchetta, L., 2003. Variations in gross biochemical composition, energy value and condition index of T. philippinarum from the Lagoon of Venice. Aquaculture 219, 859-871.

Matozzo, V., Da Ros, L., Ballarin, L., Meneghetti, F., Marin, M. G., 2003. Functional responses of haemocytes in the clam Tapes philippinarum from the Lagoon of Venice: fishing impact and seasonal variations. Can. J. Fish. Aquat. Sci. 60 (8), 949-958.

Matozzo, V., Monari, M., Foschi, J., Serrazanetti, G. P., Cattani, O., Marin, M. G., 2007. Effects of salinity on the clam Chamelea gallina. Part I: alterations in immune responses. Mar. Biol. 151 (3), 1051-1058.

Monari, M., Matozzo, V., Foschi, J., Cattani, O., Serrazanetti, G., Marin, M., 2007. Effects of high temperatures on functional responses of haemocytes in the clam Chamelea gallina. Fish Shellfish Immunol. 22 (1-2), 98-114.

Mount, A. S., Wheeler, A. P., Paradkar, R. P., Snider, D., 2004. Hemocyte-mediated shell mineralization in the eastern oyster. Science 304, 297-300.

Muñoz, P., Meseguer, J., Ángeles Esteban, M., 2006. Phenoloxidase activity in three commercial bivalve species. changes due to natural infestation with Perkinsus atlanticus. Fish Shellfish Immunol. 20, 12-19.

Ngo, T. T. T., Choi, K.-S., 2004. Seasonal change of Perkinsus and Cercaria infections in the Manila clam Ruditapes philippinarum from Jeju, Korea. Aquaculture 239, 57-68.

Oliver, L. M., Fisher, W. S., 1999. Appraisal of prospective bivalve immunomarkers. Biomarkers 4, 71-82.

Oliver, L. M., Fisher, W. S., Winstead, J. T., Hemmer, B. L., Long, E. R., 2001. Relationships between tissue contaminants and defense-related characteristics of oysters (Crassostrea virginica) from five Florida bays. Aquat. Toxicol. 55 (3-4), 
203-22.

Ordás, M. C., Ordas, A., Beloso, C., Figueras, A., 2000. Immune parameters in carpet shell clams naturally infected with Perkinsus atlanticus. Fish Shellfish Immunol. 10 (7), 597-609.

Paillard, C., 1992. Etiologie et caractérisation de la maladie de l'anneau brun chez la palourde d'élevage, Ruditapes philippinarum. Thèse de Doctorat, Université de Bretagne Occidentale, Brest.

Paillard, C., 2004a. Rôle de l'environnement dans les interactions hôtespathogènes; développement d'un modèle de vibriose chez les bivalves. Habilitation à diriger des recherches (HDR), Université de Bretagne Occidentale, Brest.

Paillard, C., 2004b. A short-review of brown ring disease, a vibriosis affecting clams, Ruditapes philippinarum and Ruditapes decussatus. Aquat. Living Resour. 17, 467-475.

Paillard, C., Allam, B., Oubella, R., 2004. Effect of temperature on defense parameters in Manila clams Ruditapes philippinarum challenged with Vibrio tapetis. Dis. Aquat. Org. 59, 249-262.

Paillard, C., Maes, P., 1990. Etiologie de la maladie de l'anneau brun chez Tapes philippinarum: pathogénicité d'un Vibrio sp. C. R. Acad. Sci. Paris 310, 15-20.

Paillard, C., Maes, P., 1994. Brown ring disease in the Manila clam Ruditapes philippinarum: establishment of a classification system. Dis. Aquat. Org. 19, 137-146.

Paillard, C., Maes, P., 1995a. Brown ring disease in the Manila clam, Ruditapes philippinarum. I. Ultrastructural alterations of the periostracal lamina. J. Invertebr. Pathol. 65, 91-100.

Paillard, C., Maes, P., 1995b. Brown ring disease in the Manila clam, Ruditapes philippinarum. II. Microscopy study of the brown ring syndrome. J. Invertebr. Pathol. 65, 101-110.

Paillard, C., Maes, P., Mazurie, J., Claude, S., Marhic, A., Le Pennec, M., 1997. Epidemiological survey of the brown ring disease in clams of Atlantic coast : role of temperature in variation of prevalence. Proceedings of the VIIIe Symposium of the International Society for Veterinary Epidemiology and Economics, 31/32, 14.03.1-14.03.3.

Paillard, C., Maes, P., Oubella, R., 1994. Brown ring disease in clams. Ann. Rev. Fish Dis. 4, 219-240.

Paillard, C., Percelay, L., Le Pennec, M., Picard, D. L., 1989. Origine pathogène de l' "anneau brun" chez Tapes philippinarum (Mollusque, Bivalve). C. R. Acad. Sci. Paris 309, 235-241.

Park, K.-I., Choi, K.-S., 2001. Spatial distribution of the protozoan parasite Perkinsus sp. found in the manila clams, Ruditapes philippinarum, in Korea. Aquaculture 203, 9-22.

Park, K.-I., Figueras, A., Choi, K.-S., 2006. Application of enzyme-linked immunosorbent assay (ELISA) for the study of reproduction in the Manila clam Ruditapes philippinarum (Mollusca: Bivalvia) II. Impacts of Perkinsus olseni on clam reproduction. Aquaculture 251, 182-191.

Pipe, R. K., Coles, J. A., 1995. Environmental contaminants influencing immune 
function in marine bivalve molluscs. Fish Shellfish Immunol. 5 (8), 581-595.

Pipe, R. K., Coles, J. A., Thomas, M. E., Fossato, V. U., Pulsford, A. L., 1995. Evidence for environmentally derived immunomodulation in mussels from the Venice lagoon. Aquat. Toxicol. 32 (1), 59-73.

R Development Core Team, 2006. R: A Language and Environment for Statistical Computing. R Foundation for Statistical Computing, Vienna, Austria, ISBN 3900051-07-0.

URL http: / /www.R-project.org

Ray, S. M., 1966. A review of the culture method for detecting Dermocystidium marinum, with suggested modifications and precautions. Proc. Natl. Shellfish. Assoc. 54, 55-69.

Reid, H. I., Soudant, P., Lambert, C., Paillard, C., Birkbeck, T. H., 2003. Salinity effects on immune parameters of Ruditapes philippinarum challenged with Vibrio tapetis. Dis. Aquat. Org. 56, 249-258.

Soudant, P., Paillard, C., Choquet, G., Lambert, C., Reid, H. I., Marhic, A., Donaghy, L., Birkbeck, T., 2004. Impact of season and rearing site on the physiological and immunological parameters of the Manila clam Venerupis (=Tapes, =Ruditapes) philippinarum. Aquaculture 229, 401-418.

Tiscar, P. G., Mosca, F., 2004. Defense mechanisms in farmed marine molluscs. Vet. Res. Commun. 28, 57-62.

Truscott, R., White, K., 1990. The influence of metal and temperature stress on the immune system of crabs. Fisheries Research 4 (3), 455-461.

Villalba, A., Casas, S., Lopez, C., Carballal, M., 2005. Study of perkinsosis in the carpet shell clam Tapes decussatus in Galicia (NW Spain). II. Temporal pattern of disease dynamics and association with clam mortality. Dis. Aquat. Org. 65 (3), 257-267.

Villalba, A., Reece, K. S., Camino Ordás, M., Casas, S. M., Figueras, A., 2004. Perkinsosis in molluscs: A review. Aquat. Living Resour. 17, 411-432. 